\title{
A Comprehensive Review on Emerging Importance and Economical Potential of Medicinal and Aromatic Plants (MAPs) in Current Scenario
}

\author{
Umair Riaz $^{1 *}$, Shazia Iqbal ${ }^{2}$, Muhammad Irfan Sohail', Tayyaba Samreen², Muhammad Ashraf', Fatima \\ Akmal $^{2}$, Ayesha Siddiqui ${ }^{3}$, Ijaz Ahmad ${ }^{4}$, Muhammad Naveed ${ }^{5}$, Naveed Iqbal Khan ${ }^{5}$ and Rao Masood \\ Akhter $^{6}$
}

${ }^{1}$ Soil and Water Testing Laboratory for Research, Bahawalur-63100, Agriculture Department, Government of Punjab, Pakistan; ${ }^{2}$ Institute of Soil and Environmental Sciences, University of Agriculture, Faisalabad 38040, Pakistan; ${ }^{3}$ Department of Botany, University of Agriculture, Faisalabad 38040, Pakistan; ${ }^{4}$ Ecotoxicological Research Program, National Agricultural Research Centre, Islamabad, Pakistan; ${ }^{5}$ Soil and Water Testing Laboratory for Research, Lahore, Agriculture Department, Government of Punjab, Pakistan; ${ }^{6}$ Regional Agricultural Research Institute, Bahawalpur, Agriculture Department, Government of Punjab, Pakistan.

Abstract | The medicinal and aromatic plants (MAPs) are current hot topic in the industries for their products. MAPs used in various items like pharmaceutical industry, health care items, cosmetics, organic food items etc. MAPs are gaining global admire and most of the pharmaceutical companies filing patents on medicinal plants and their derivatives and about $40 \%$ newly approved drugs during last two decades are formulated from natural origin. Multitude of socio-economic factors influence economic values of medicinal plants both locally and at international level. The world trade in botanicals is US \$32.702 billion and Asian botanical trade is for US $\$ 14.505$ billion with 6.634 million tones and accounts for 44.35 per cent and 53.13 per cent of world trade in terms of value and volume, respectively. Following the leading role of China with $1.48 \%$ share in MAPs exports, India is second largest exporter of MAPS with $8.75 \%$ share in Asian trade of MAPs. Various biomass and leftover produced with these plants production, as the MAPs cultivation withstands a huge economic potential, but it has several limitations to adaptation as arable crops i.e. lower prices, non-availability of transit markets, underdeveloped cultivation technology, poor availability of cultivation resources and genetic materials and many more. Therefore, MAPs can be cultivated and adopted to various geographical landscapes if facilitated by governments especially in the rural areas of low-income Asian and African countries.

Received | November 19, 2020; Accepted | March 07, 2021; Published | May 04, 2021

*Correspondence | Umair Riaz, Soil and Water Testing Laboratory for Research, Bahawalur-63100, Agriculture Department, Government of Punjab, Pakistan; Email: umairbwp3@gmail.com, umair.riaz@uaf.edu.pk

Citation | Riaz, U., S. Iqbal, M.I. Sohail, T. Samreen, M. Ashraf, F. Akmal, A. Siddiqui, I. Ahmad, M. Naveed, N.I. Khan and R.M. Akhter. 2021. A comprehensive review on emerging importance and economical potential of medicinal and aromatic plants (MAPs) in current scenario. Pakistan Journal of Agricultural Research, 34(2): 381-392.

DOI | https://dx.doi.org/10.17582/journal.pjar/2021/34.2.381.392

Keywords | Economic determinant, Human health, Medical and aesthetic potential, Sustainability, Trade potential

\section{Introduction}

A romatic plants contain odorous volatile substances that exist in one or more sections as an essential oil, exudate gum, balsam, and oleoresin, including root, wood, bark, stem, foliage, flower, and fruit. Several complex chemical compounds are responsible for the distinctive fragrance. The term June 2021 | Volume 34 | Issue 2 | Page 381 
essential oils are synonymous with fragrances or fragrances, as these oily fragrances reflect the essence or active elements of the plants. When you are exposed to air at normal temperatures, you are called volatile or ethereal oils. Critical oils are products with high concentration and low volume. Information on the chemistry and properties of essential oils of only about 500 species is currently known in some detail out of a total of about 1500 species of aromatic plants which serve as a source of raw materials for the perfumery. Of these, approximately 50 species use essential oils and aroma chemicals as a commercial source, although the number of those with daily and large-scale usage hardly exceeds two dozen.

Since then, the world of essential oils has expanded from the narrow area of description to a wide variety of applications in flavors, disinfectants, oral hygiene, cigarettes, pharmaceuticals and in virtually every sphere of human activity. Essential oils make up about $17 \%$ of the worldwide flavor and fragrance market. World production figures for essential oils range from 40,000 to 60,000 tons per annum. Spice oils demand is set at 2,000 tons per year (Joy et al., 2001). At the beginning of the twenty-first century, foreign market reports estimated the consumption of flavors and fragrances to be around US\$ 8 billion (Bernáth, 2009).

Basic oils, or volatile oils, occur very commonly in the plant kingdom. Plants with essential oils were known, or even used in religious ceremonies, or for personal use, ornamentation, and flavoring foods long before history was documented. Hundreds of aromatic substances like cinnamon, ginger, and sandalwood were recorded around $2000 \mathrm{BC}$ in the Vedic literature in India. Also, in dynastic Egypt, essential oil crops were widespread, and traces of the essential compounds could be detected in the funerary jars and cosmetic pots found in the tombs of the Pharaohs. The Greeks took the Egyptian knowledge, which Romans further developed, and applied it. Some six hundred plants and aromatics were detailed in the "De materia medica," written by Dioscorides. Hippocrates (460 BC) recommended the fumigation and fomenting of perfumes. At that time Romans distinguished three specific forms of perfumery: strong unguent "ladymata," scented "ladysmata" oils and perfumed "diapasmata" powders. From that ancient practice, the European application of essential oils has evolved, backed by experience from Persia, the Far East, and the New World (Bernáth, 2009). In Asian countries, plants are used for medicinal purpose since ancient times. In recent era cultivation of medicinal and aromatic plants became an emerging export industry in many Asian countries. India has one of the richest sources of many types of MAPs, however, since farmers are not aware of their potential and returns they have achieved little success in tapping the potential of these plants (Purohit and Vyas, 2004). China exports plants and raw drugs, therapeutics and other MAPs worth Rs 18,000 crores annually (Singh et al., 2007). In Nepal Himalaya, about 1800 MAPs are used for subsistence economy (Baral and Kurmi, 2006).

Turkey and Egypt are also a major exporter of aromatic and medicinal plants. Hong Kong, Japan, China, Korea, Pakistan and Singapore are leading exporter of MAPs from south Asia. Apart from these countries, Pakistan, Bangladesh, Afghanistan, Maldives had understood the importance of this industry and they are promoting the growth of these plants on commercial level.

Essential oils and chemical flavorings make up a wide number of industrial products. In many spheres of human life, these oils form essential ingredients of necessities. These are adjuncts to cosmetics, soaps, medicinal products, perfumery, confectionery, icecreams, disinfectants from aerated waters, tobacco, agarbathis, and a host of related products. Natural substances are healthy and pleasant. The concern for nature and the passion for all simple and natural things have contributed to a green movement in the world of both natural and manufactured consumer goods. A future surprise awaits the industry, as on one hand the already dwindling world coal and petroleum resources and on the other hand, the concept of returning to nature is gaining international acceptance. This will revert the industry 's reliance on the petrochemicals to the natural perennial source. Thus, the essential oil and fragrance industry has a promising future due to a broad range of uses in man's daily life.

In today's market boom world, several folds have increased the position of essential oils. Besides the already established uses of essential oils, more and more areas are being opened which will support the industry (Joy et al., 2001). The production and use of essential oils are increasingly growing due to their multipurpose application: Essential oils are used in the perfumery, in the food industry, in the 
domestic industry, in the condiment industry and the manufacture of sweets and beverages as well as medicinal and aromatherapy products of plant origin (Bernáth, 2009). In Japan and European countries, the use of essential oils is becoming common in therapeutics (Joy et al., 2001). Aromatherapy includes the use of plant-derived essential oils and aromatics to treat diseases. Many of the essential oils are stated to be better than antibiotics in several respects, due to their protection and broad activity range. Critical oil's synergistic behavior requires more investigation. Application of essential oils as an antifeedant, repellents, botanical insecticides, natural herbicides, and growth boosters in agriculture is still open to fascinating research fields. The synthesis of secondary metabolites in bioreactors using cell and tissue culture under controlled conditions provides exciting frontiers for future study (Joy et al., 2001).

\section{Economic parameters}

For the export purpose, various parameters were established for aromatic plants. For oil-producing plants a balanced ratio of monoterpene ketones which are responsible for better olfactory value (Panda, 2005).

Crop management: Aromatic plants demand intensive management. Different species require their distinct conditions of cultivation. In many medicinal and aromatic plants, plant characteristics differ widely with soil type and crop strategy, so care must be taken to achieve sufficient yields (Carrubba and Scalenghe, 2012) Cultivation may be conventional or may use conservation farming practices to retain organic matter in the soil and to conserve water, for instance with tillage-free farming. The World Health Organization advises making use of rotation to mitigate insect and plant disease problems (WHO, 2003).

Distillation: Different plant parts of aromatic plants are used for different purposes. Flower parts are used as a scent. Essential oil is present in its leaves, seeds, and flowers. The stem did not contain any oil. The age of leaves and flowers affects the quality and content of the oil. More ratio of leaves and flowers to stem produces more oil. Crop cultivation should be done at the full blossom stage to get more yield of herb and good quality of the oil. Steam distillation is done to get oil from plants. Fresh herbs material harvested at full blossom or shade dried herbs for 2-3 days is used for distillation. Green herbs should not be piled in heaps. It should be spread under shade thoroughly. Fresh herb distillation gives better quality oil (Panda, 2005).

\section{Quality Evaluation, advertising, and labeling:} Quality evaluation of aromatic plants includes its freshness, viability, and contents. In the case of oil production, the chemical composition of the oil is considered the most important parameter (Panda, 2005). Herbal and dietary supplement products have been criticized for not providing adequate criteria or empirical evidence to support their quality, protection, and presumed efficacy (Coghlan et al., 2012; Zhang et al., 2012). In 2013 report, one-third of the herbal products tested did not contain traces of the herbal products specified on the label, and other products were adulterated with non-listed fillers and possible allergens (Newmaster et al., 2013). Oil should be stored in aluminum containers or amber-coloured bottles. They should be well packed up to the brim and should be kept completely moisture-free. Storage causes various changes in the quality of aromatic plant products (Panda, 2005).

\section{Role of medicinal and aromatic plants in the economy of} the country

Several countries exporting MAPs like Turkey is exporting medicinal and aromatic plants to about 100 countries worldwide. North America, the European Union, Latin America, the Far East, and North Africa account for a substantial part of its international revenues. The list includes the United States, Germany, Vietnam, The Netherlands, Poland, Brazil, Canada, Italy, Belgium, Greece, France, and Japan. Big medicinal and spice thyme plants, bay leaf, cumin and anise, fennel seeds, juniper bark, hlep, fenugreek, rosemary, basil, sumac, sage, and lime are grown from Turkey. The data regarding 12 leading countries of import and export of medicinal and aromatic plant material from 1991-2003 showed in Table 1. The MAPs exports and imports of Turkey in 2018 showed in Table 2. The products which are most exported are oregano and laurel. A total of 80 thousand tons of medicinal and aromatic plants were exported in 2018, and revenue totaling USD 265 million (Table 2). The major imports into Turkey include tea, pepper, anise, oregano, cumin, ginger, and carob. Many of the imported goods, however, are handled within the framework of the inward processing regime and exported abroad again. Turkey 's cumulative 
Table 1: The 12 leading countries of import and export of medicinal and aromatic plant material, 1991-2003 (Lange 2006).

$\begin{array}{llllll}\text { Country of import } & \text { Volume [tonnes] } & \text { Value [1000US\$] } & \text { Country of export } & \text { Volume [tonnes] } & \text { Value [1000 US\$] } \\ \text { Hong Kong } & 59,950 & 263,484,200 & \text { China } & 150,600 & 266,038,500 \\ \text { USA } & 51,200 & 139,379,500 & \text { Hong Kong } & 55,000 & 201,021,200 \\ \text { Japan } & 46,450 & 131,031,500 & \text { India } & 40,400 & 61,665,500 \\ \text { Germany } & 44,750 & 104,457,200 & \text { Mexico } & 37,600 & 14,257,500 \\ \text { Rep. Korea } & 33,500 & 49,889,200 & \text { Germany } & 15,100 & 68,243,200 \\ \text { France } & 21,800 & 51,975,000 & \text { USA } & 13,050 & 104,572,000 \\ \text { China } & 15,550 & 41,602,800 & \text { Egypt } & 11,800 & 13,476,000 \\ \text { Italy } & 11,950 & 43,006,600 & \text { Bulgaria } & 10,300 & 14,355,500 \\ \text { Pakistan } & 10,650 & 9,813,800 & \text { Chile } & 9,850 & 26,352,000 \\ \text { Spain } & 9,850 & 27,648,300 & \text { Morocco } & 8,500 & 13,685,400 \\ \text { UK } & 7,950 & 29,551,000 & \text { Albania } & 8,050 & 11,693,300 \\ \text { Malaysia } & 7,050 & 38,685,400 & \text { Singapore } & 7,950 & 52,620,700 \\ \text { Total } & 320,550 & 930,524,400 & \text { Total } & 368,100 & 847,980,800 \\ \text { Figures based on commodity group pharmaceutical plants (SITC.3: } 292.4=H S \text { 1211). Source: UNCTAD COMTRADE database, United } \\ \text { Nations. Statistics Division, Nerw York. } & & & \end{array}$

medicinal and aromatic plants account for just over 38,000 tons of imports, although its monetary equivalent is just over $\$ 79$ million. In terms of monetary value, the most crucial import element is green and black tea (Karik and Tunçtürk, 2019).

\section{Production and trade of essential oils in Turkey}

Turkey's global sales of essential oils for 2018 amounted to about $\$ 42$ million. The principal products are rose oil, stearopten oil, and oregano oil (Table 3). Increased international sales of essential oils in Turkey in recent years seem to have contributed to a rise in the amount of essential oils in the plants. Especially in the thyme, laurel, mint, rosemary, cumin, myrtle, lemon leaf, anise, and aromatic herbs such as aphids are produced from essential oils in Antalya, Manisa, Mersin, Mugla and Hatay province. A major part of important oil exports is made to EU countries. As of 2018, France, Germany, Australia, the USA, Switzerland, England, Greece, Ireland, Bahrain, Canada, and Spain were the largest exporting nations. France's share of total exports is $53 \%$. Nearly all of the rose oil produced in Turkey is exported. 2018 International trade amounts to about $\$ 14$ million. Major exports were made to $\mathrm{EU}$ countries, USA, Switzerland, Bahrain, Kuwait, Japan, UAE, Australia, Azerbaijan, Turkmenistan, Iraq and the Republic of Northern Cyprus in Turkey. France's share of overall foreign exports of oil was $62 \%$, Germany's share was $13 \%$, the US share was $10 \%$, and Switzerland had a 9\% share. Table 3 includes essential oils that have been imported into Turkey. The main essential oils imported into Turkey include oregano, lime, lemon, other citrus oils, and peppermint oil. The total volume of essential oils imported in 2018 was 552 tons and roughly $\$ 26$ million (Karik And Tunçtürk, 2019).

\section{Economic parameters to understand the value of medicinal} plants

In terms of the number of species, MAPs represent one of the major human consumption of the natural world. The value, utility and worth of these plants to livelihoods of the people is fathomless. It may be indicated in terms of their contribution to financial income, cultural identity, healthcare and livelihood security, however the direct contribution of these plants to a country's economy are estimated in many ways (Hamilton, 2004). In last few decades, the international trade for indigenous medicinal plants and plant-based drugs have increased manifolds (Hamilton, 2013). Multi-million portion of developing countries is based on international trade of medicinal plants (Mander and Le Breton, 2006). With paramount increase in popularity of herbal products, such trades are likely to expand markedly by the year 2050 (Lange and Mladenova, 1997).

The MAPs trade is major shareholder of GDP to agriculture in any agro-based country or geographical locations abundant in natural vegetations. It is prerequisite to explore the potentials of MAPs as arable crop into routine agriculture. There are various 
indicators or set of parameters which can represent the true value, sustainable cultivation and trade of MAPs for farmer and national benefits. The main driver for the cultivation of medicinal plants could be in two components i.e. pull and push effects. The pull effects refer to the factor that attract farmers to cultivate MAPs, rather than traditional crops. These factors include attractive prices, fixed market channels, price assurance by agents and monopoly of the group of producers in cultivating these crops. Whereas, push effects are dominated by the uncertainty of net income generated from the traditional seasonal crops due to factor and product market imperfections. Well-established market channels prompt farmers to cultivate MAPs (Chandresh et al., 2014). Therefore, under the current climatic shifts, low productivity of traditional field crops has significantly pushed the farmers towards medicinal crops for profit maximization. The MAPs foster the economic windows for unshielded groups of farmers in peri urban and marginalized lands.

Table 2: Medicinal and aromatic plants exports and imports of Turkey in 2018 (Anonymous, 2019).

\section{Product}

\begin{tabular}{|c|c|c|c|c|}
\hline & Amount (kg) & Value (US \$) & Amount (kg) & Value (US \$) \\
\hline Oregano & $16,212,000$ & $52,331,000$ & $1,787,584$ & $4,750,033$ \\
\hline Laurel Leaf & $13,253,940$ & $36,716,616$ & 989,611 & $1,523,208$ \\
\hline Cumin & $6,455,169$ & $19,500,621$ & $1,003,631$ & $3,290,609$ \\
\hline Anis seed & $2,418,735$ & $9,637,809$ & $3,612,533$ & $6,589,114$ \\
\hline Sage & $1,824,818$ & $6,695,586$ & 743,980 & $1,620,684$ \\
\hline Sumac & $2,108,382$ & $4,491,056$ & 461,260 & 113,673 \\
\hline Licorice & $1,069,961$ & $3,102,837$ & $1,102,153$ & $1,985,376$ \\
\hline Spice Mix & 300,476 & $2,006,843$ & 3,374 & 45,123 \\
\hline Mahaleb & 123,283 & $1,242,394$ & $19,903^{\prime}$ & 92,954 \\
\hline Spearmint & 620,292 & $1,876,792$ & 87,241 & 133,100 \\
\hline Rosemary & 493,389 & $1,477,264$ & 619,752 & 839,080 \\
\hline Black Cumin & 404,691 & 983,074 & $3,678,628$ & $7,312,482$ \\
\hline Carob & $2,421,351$ & $18,433,777$ & $2,462,071$ & $4,166,059$ \\
\hline Linden & 116,741 & $1,521,480$ & 25,151 & 54,442 \\
\hline Turmeric & 45,704 & 201,441 & 979,376 & $1,096,073$ \\
\hline Cinnamon & 38,505 & 234,165 & 873,560 & $1,542,843$ \\
\hline Coriander & 142,351 & 187,920 & 522,207 & 275,604 \\
\hline Clove & 5,555 & 99,894 & 279,113 & 482,837 \\
\hline Thyme & 48,547 & $1,287,456$ & 6,276 & 6,826 \\
\hline Saffron & 4,602 & 89,848 & 91 & 20,187 \\
\hline Ginger & 26,368 & 116,984 & $2,990,512$ & $3,295,411$ \\
\hline Curry & 24,723 & 78,260 & - & - \\
\hline Fenugreek & 168,004 & 298,736 & 340 & 1,322 \\
\hline Cardamom & 3,368 & 54,872 & 204,675 & 871,164 \\
\hline Nutmeg & 10,125 & 55,425 & 45,820 & 58,087 \\
\hline Poppy seed & $25,286,661$ & $73,736,971$ & 45,950 & 125,069 \\
\hline Morphine & 25,647 & $8,434,688$ & 2 & 368 \\
\hline Tea & $3,321,866$ & $12,035,946$ & $15,635,054$ & $38,911,087$ \\
\hline Other Spices & $2,985,503$ & $8,233,055$ & 69,633 & 34,799 \\
\hline Total & $79,960,757$ & $265,162,810$ & $38,249,481$ & $79,237,614$ \\
\hline
\end{tabular}

\section{Exports}

Value (US \$)

$19,500,621$

$4,491,056$

$1,242,394$

983,074

, 433,777

441

187,920

54,872

55,425

$8,434,688$

$265,162,810$
Imports

Value (US \$)

$3,290,609$

$1,620,684$

$1,985,376$

45,123

839,080

$4,166,059$

,073

275,604

1,322

368

34,799

$9,237,614$ 
Table 3: Essential oil exports and imports of Turkey in 2018 (Anonymous, 2019; Karik and Tunçtürk, 2019).

\begin{tabular}{lllll} 
Product & \multicolumn{2}{c}{ Exports } & \multicolumn{2}{c}{ Imports } \\
& $\begin{array}{l}\text { Amount } \\
(\mathbf{k g})\end{array}$ & $\begin{array}{l}\text { Value }(\mathrm{SS} \\
\text { Amount }\end{array}$ & $\begin{array}{l}\text { Value (US } \\
(\mathbf{k g})\end{array}$ & $\$$ ) \\
Oregano oil & 65,000 & $5,501,000$ & 1,790 & $4,864,492$ \\
Spearmint oil & 16,000 & 168,895 & 11,985 & 339,135 \\
Rosemary oil & 55 & 5,723 & 1,262 & 63,613 \\
Lavandula oil & 3,851 & 129,354 & 5,062 & 289,972 \\
Rose oil & 16,369 & $14,136,625$ & 5,954 & 233,717 \\
Lemon oil & 3,121 & 131,230 & 380 & $1,996,689$ \\
Pepermint oil & 1,212 & 44,566 & 243,607 & $3,189,027$ \\
Other citrus oil & 4,822 & 113,459 & 64,406 & $2,239,109$ \\
Maceration & 280,547 & $6,615,909$ & 55,676 & $1,996,950$ \\
Hydrosol & 364,240 & $1,921,192$ & 31,833 & $2,268,460$ \\
Other essential & 57,922 & $13,754,416$ & 130,785 & $8,941,328$ \\
oil & & & & \\
Total & 813,139 & $42,522,369$ & 552,740 & $26,422,492$
\end{tabular}

\section{Economic parameters of local market value}

According to Williams et al. (2007), the market value of individual plant taxon depends on a multitude of factors and therefore it varies considerably.

- Generally, there is a disproportionate and inverse relationship between price per unit and the mass of the product vended. Sale values are subordinate for the sales of higher quantities of the product relative to the sales of lower quantities. For instance, plant part types such as bark and bulbs, given the larger quantity sold, have inferior values relative to other parts such as fruits, leaves and roots of the plants.

- The price of harvesting plant species fluctuates based on access of the harvester to the resources and the distance of trading markets from the harvesting sites.

- Prices also vary based on negotiations between sellers and buyers in local markets for purchasing indigenous products.

- Although, information on purchase/buying prices for medicinal plants and actual quantities being sold is sparse, because of incomplete records and often prohibited and outlawed nature of the trade. But, with the increase in demand, and thereby upsurge in value and quantity being sold, it may overexploit the resources hence, actual prices may vary.

Economic determinants of international market value International market values and economic indicators of MAPs are based on a variety of factors. "Supply and demand" are the simplest equation that applies to every international trade (Agcaoili and Rosegrant, 2010) including both categories of "high value minor" crops such as MAPs. The contribution of these crops to a country's agricultural output is relatively low but has substantially amplified in the past decade due to growing demand of these plants in the healthcare sector globally (Khan et al., 2011). The developed countries such as Europe and USA are devising medicinal systems that necessitate the use of herbal products and resources. Therefore, a marked increase in global demand of MAPs has seen in the recent years, and it has provided an ample opportunity to MAPs exporting countries to expand their economy share in this sector. The major consumers of the MAPs are USA, Europe and Japan, while nearly $30 \%$ of the global export is made up by Morocco and Egypt (Africa), India and China (Asia), Albania and Bulgaria (Europe) and Peru and Chile (South America) (Vasisht et al., 2016). About 80\% of World's MAPs supply is from local indigenous plants (Bernholz, 2004). Among major products to be traded from MAPs are (i) Phyto-pharmaceuticals (ii) Nutraceuticals and (iii) Cosmeceuticals.

In the recent years, the global demand of spices, herbs and MAPs has boosted up several folds, due to increasing interest of healthcare sector in the therapeutic properties of phytochemicals associated with indigenous medicinal plants. Present-day industrial utilization of these plants to produce herbals teas, extracts, decoctions, nutraceuticals, plant-based pharmaceuticals, and cosmeceuticals has been growing faster than the conventional medications and drugs. Thus, MAPs-based industrial sector has enormous potential for the economic growth of a country (Gunjan et al., 2015). Several precursor molecules of the herbal drugs are directly or indirectly obtained from MAPs, for example, quinine is derived from Cinchona officinalis and digitoxin from Digitalis purpurea to treat malaria and cardiac problems, respectively. Likewise, many other phytochemicals and their derivatives such as paclitaxel, scopolamine, vincristine, pilocarpine, atropine and morphine are obtained from medicinal plants and share a significant portion in international global trade of related MAPs (Roosta et al., 2017). The overall international market for the trade of herbal drugs was valued at approximately USD 23 billion in 2013, USD 24 billion in 2014 and USD 25 billion in 
2015. This value has been estimated to increase with compound growth rate of approximately $7 \%$ annually, reaching USD 36 billion in 2020 (Lawson, 2013).

Nutraceutical is the term applied to food products that are supplemented with vitamins, herbal ingredients, minerals, as part of several bioactive food products, dietary supplements and fortified beverages and food items. Global nutraceutical market has increased rapidly in past few decades. For instance, in USA alone $76 \%$ of adults are regular users of food supplements (Travis et al., 2019). Countries such as Malaysia, Thailand, Singapore and Philippines have seen an $8.4 \%$ annual overall compound growth rate in nutraceutical industry. About $40 \%$ of the population from Southeast Asia use nutraceuticals on regular basis (Tripathi et al., 2020). According to WHO 80\% of African and Indian population are heavily dependent on indigenous herbal products and supplements for the treatment of common ailments. Therefore, there has been a constant upsurge in supply and demand of these herbal supplements (Bahorun et al., 2019).

Recently, natural ingredients based personal care items and cosmetics are excessively favorable trend in the global market. These cosmetic products possess the physiological active components that could cure skin problems and have desired antioxidant, smoothing, soothing and conditioning properties (Draelos, 2019). Therefore, with the invention of enhanced technologies in makeup, skin care and hair care products, this sector has strong economic impacts on a country's economy (Kim, 2016). For instance, Aloe Vera (Aloe barbadensis) is extensively used in cosmetic industry based on its natural sun-protection and soothing properties. Likewise, Ginkgo biloba, Panax spp, Withania somnifera, Serenoa repens are being used in replacement of synthetic vitamins for the treatment of skin and hair related problems. Similarly, many age-defying, hair growth stimulants and retardants, sun protecting lotions and creams, facial peels and masks and other products contain natural ingredients, therefore, the consumption, production and export of related medicinal plants have been increased manifolds (Dorni et al., 2017; Rao et al., 2017; More, 2019). Global market of cosmeceutical was USD 44 billion in 2017 and it is extrapolated to grow at a rate of 7\% annually. Likewise, market share of USA was USD 2.8 billion in 2001 that increased by more than $7 \%$ annually through 2012. Therefore, it is an important indicator of economic value of herbal products with exponentially increasing global demand.

Indicators and parameters for sustainable cultivation and trade of MAPs

The production and consumption; and international import and export of MAPs can be regarded as important economic indicators. Although, it is challenging to estimate the exact figures on global demand of MAPs; however, trends can be extrapolated using already available data. There is an increasing human tendency to use MAPs for pharmacological reasons and recreational purposes due to natural drugs being cost-effective, safer, and easily accessible by majority of the population worldwide. Moreover, the current COVID-19 pandemic around the globe has further pushed the public to rely on herbs for their immunity and the trends are increasing since 2019. However, multiple factors viz., socio-economic, cultural, environmental, and geographical variables influence economic indicators of medicinal plants. There are several indicators which represent the sustainable and prospect cultivation and trade of MAPs. An overview has been presented in Figure 1.

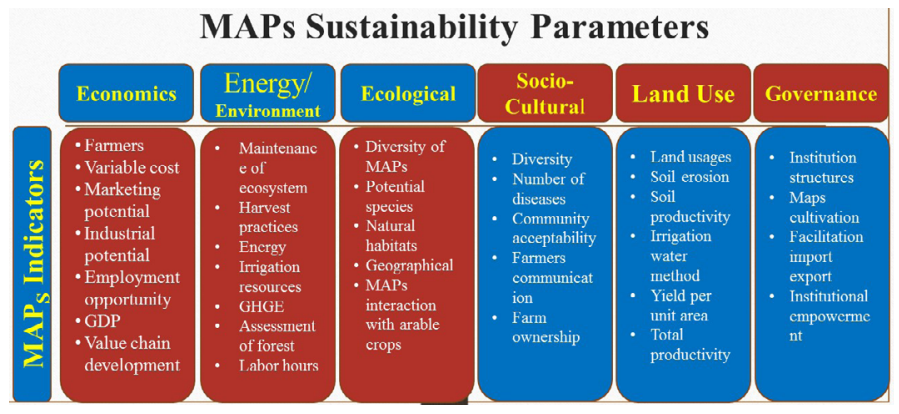

Figure 1: MAP sustainability parameters.

Multitude of socio-economic factors influences economic values of medicinal plants both locally and at international level. Surveys and researches conducted on local cultures in many regions have indicated that number of farm patches owned by locals, marital status of cultivators, annual income specially from growing staple crops and related utilization of the land are most influential factors on consumption and trade of medicinal plants (Khan and Rauf, 2014). However, there is a dire need to provide necessary facilities and better financial capitals to interested growers to upsurge trade into medicinal plants both at local and global level. It is also suggested to study profitable cultural aspects leading to enhance harvesting and maintenance of medicinal plants at local level. Domestication of in-demand medicinal plants by the cultivators can also positively influence 
its trade. All these factors may contribute to the value of medicinal plants and hence can be observed via economic indicators (Niyaki et al., 2011).

Economic factors such as property and production value of the land being used for the cultivation is also dependent on the fertility and capacity of the soil to grow such plants. Similarly, other ecological factors such as regularization of indigenous MAPs collection from wild, strategies regarding conservation of individual species and ecosystems are imperative to its economic output. Such knowledge will also clarify and thereby reducing the anthropogenic compression on natural resources for the cultivation of MAPs (Kuniyal et al., 2013). Therefore, these environmental factors also play significant role in determining of the value of MAPs. All these factors are interconnected for example, socio-economic well-being of agricultural communities, efficiency indicators and land use indicators. Whereas, efficiency indicator of MAPs values includes use of resources per acre or other units. It measures impact over time in relation to our capacity to fulfill productivity demands (Field to Market Report, 2012). Likewise, land use indicators demonstrate that how much area is dedicated to the production of in-demand medicinal plants (Van den Bergh and Grazi, 2014).

Role of medicinal and aromatic plants (MAPs) in GDP The MAPs are not only fundamental to civilizations around the globe as basic preventive and curative health cares, but these has been also the cornerstone for sustainability of civilizations, source of incomes and trade. Though the medicinal plants belong to natural habitat but the better economic opportunities against the traditional field crops has led their cultivation under field conditions around the globe especially in Asia, Africa and Europe (Mohapatra et al., 2018). The distribution of medicinal plant species on earth is not equal, but also differs in geographical regions of the same generation. The tropical regions are the richest species in terms of species diversity. The total contribution to any national agriculture output of MAPs may be small, but their value per weight is among the highest among traded plants and adds significant growth to gross domestic products. An average annual income of 5000 USD per hectare can be obtained through mixed cropping of high-altitude medicinal herb. Even the high-altitude villages earn their $10-50 \%$ livelihood income from wild MAPs. it is estimated that current market of medicinal plants has a figure of more than 107 billion dollars annually (Karik and Tancturk, 2019). The global nutraceutical market is expected to reach US $\$ 278.96$ billion by the end of 2021, with a growth rate of $7.3 \%$ per annum. Therefore, The World Bank expects the trade of medicinal plants to grow up to a trading value of five trillion USD by 2050 (Bucher et al., 2020). China is the world's biggest exporter of MAPs and Japan; USA and Germany are the leading importers (Bucher et al., 2020). But the global supply chain of MAPs is mainly regulated through developing countries of Asia, Africa and N. America (Karik and Tancturk, 2019).

The world trade in botanicals is US $\$ 32.702$ billion and Asian botanical trade is for US $\$ 14.505$ billion with 6.634 million tones and accounts for 44.35 per cent and 53.13 per cent of world trade in terms of value and volume, respectively (Karki, 2017). Following the leading role of China with $1.48 \%$ share in MAPs exports, India is second largest exporter of MAPS with $8.75 \%$ share in Asian trade of MAPs (Karki, 2017). In Bangladesh, about 12,000 tons of MAP materials worth US $\$ 4.5$ million but Bangladesh also imports more than 5000 tons of material worth US\$ 8 million. The domestic market of herbal medicines in Bangladesh is valued at US $\$ 60$ million (Merry and Shahjahan 2013). Similarly, Nepal's trade in MAPs is more than USD 33 billion dollar annually (Pyakurel et al., 2019). In 2012, Pakistan exported MAPs worth over US $\$ 10.5$ million (Sher et al., 2014). From only Asia and Africa, the Europe's import of MPAPs is about USD 1 billion (Zahra et al., 2020). Malaysian herbal industry produces a business of USD 315 million annually with steady growth rate of $20 \%$. For example, Mander et al. (2007) estimated that South Africa produces an income about $5.6 \%$ of the National Health budget. Similarly, in China 40-63\% of household income originates from the trade of medicinal plants (Boesi, 2014). Rasethe et al. (2019) presented that $90 \%$ of MAPs business in Malawi derives $>50 \%$ of households' income. Similarly, over 61000 kilograms of medicines valued US $\$ 344,882$ provides business to Tanzania per year. The annual revenues produced in Morocco and Egypt for export of MAPs was US $\$ 55.9$ and US $\$ 174,227,384$ million in 2015, respectively. About 951 tons of raw herbs worth of US\$7.8 million was traded in Ghana's in 2010. Karik and Tancturk (2019) presented that in year 2018, about 300.000 tons of MAPs were produced in approximately and exported share generated 
265 million US dollars of revenue for Turkey. A large quantity of residual biomass (solid, liquid, and gaseous) is produced every year from the agricultural sector throughout the world, which is supposed to be the most plentiful, economic and renewable resource on earth. There is a scope for dual utilization of residual biomass i.e. extraction of phytochemicals and further conversion into value added products. A brief list of aromatic plants with respect to their plant part usage and source of attain showed in Table 4.

\section{Table 4: Selective list of aromatic plants.}

\begin{tabular}{|c|c|c|c|}
\hline Botanical Name & English Name & $\begin{array}{l}\text { Part of } \\
\text { plant used }\end{array}$ & $\begin{array}{l}\text { Obtain } \\
\text { From }\end{array}$ \\
\hline Abies Webbiana & Indian Silver Fir & Leaves & Wild \\
\hline Betula utilis & $\begin{array}{l}\text { Himalaya silver } \\
\text { birch }\end{array}$ & Bark /leaf & Wild \\
\hline Borago officinalis & Borage & Herb & Cultivated \\
\hline Calendula officinalis & Marigold & Flower & Cultivated \\
\hline Ephedra gerardiana & Ephendra & Herb & Wild \\
\hline Erigeron canadensis & Horse Weed & Herb & Cultivated \\
\hline $\begin{array}{l}\text { Fagopyrum esculen- } \\
\text { tum }\end{array}$ & Buckwheat & Herb & Cultivated \\
\hline Gnaphalium & Cotton weed & Herb & Wild \\
\hline Hedera helix & Ivy & Leaves & Wild \\
\hline Humulus lupulus & Common Hop & Ketkin & Cultivated \\
\hline Inula racemosa & Elecampane & Root & Cultivated \\
\hline Iris germanica & Orris & Root & Wild \\
\hline Juglans regia & Walnut & Leaves & Cultivated \\
\hline Juniperus communis & Common juniper & Seed & Wild \\
\hline Melilotus officinalis & $\begin{array}{l}\text { Yellow sweet } \\
\text { clover }\end{array}$ & Herb & Cultivated \\
\hline Mentha aquatica & Water mint & Herb & Wild \\
\hline $\begin{array}{l}\text { Nardostachys jata- } \\
\text { mansi }\end{array}$ & Spikenard & Root & Wild \\
\hline Origanum vulgare & Oregano & Herb & Wild \\
\hline Parmelia perlanta & Stone flower & Moss & Wild \\
\hline Passiflora incarnata & $\begin{array}{l}\text { Wild passion } \\
\text { flower }\end{array}$ & Herb & Cultivated \\
\hline Quercus robur & Common oak & Seed & Wild \\
\hline Rosa canina & Dog rose & Flower & Wild \\
\hline Salix alba & White willow & Bark & Wild \\
\hline Taraxacum officinale & Dandelion & Herb & Cultivated \\
\hline Urtica dioica & Nettle & Herb & Wild \\
\hline Valeriana wallichii & Indian valerian & Root & Cultivated \\
\hline Verbascum thapsus & Common mullein & Herb & Wild \\
\hline $\begin{array}{l}\text { Zanthoxylum acan- } \\
\text { thopodium }\end{array}$ & Toothache tree & Seed & Wild \\
\hline
\end{tabular}

Source: https://www.saussurea-costus.com/list-of-medicinaland-aromatic-plants/ accessed 12-05-2020.

\section{Conclusions and Recommendations}

This review article depicted the economical values of medicinal and aromatic plants globally. As data showed there is a great potential in these areas with respect to export and GDP factors. Whereas, these plants are sensitive in nature and to some extant tricky in handling. They need special care in terms of production, growth, storage, and supply to the market. The MAPs cultivation withstands a huge economic potential, but it has several limitations to adaptation as arable crops i.e. lower prices, non-availability of transit markets, underdeveloped cultivation technology, poor availability of cultivation resources and genetic materials and many more. Therefore, MAPs can be cultivated and adopted to various geographical landscapes if facilitated by governments especially in the rural areas of low-income Asian and African countries.

\section{Novelty Statement}

The medicinal and aromatic plants hold potential to boost GDP and econo-my as reviewed by this article of various countries.

\section{Author's Contribution}

Umair Riaz: Idea executor and overall manage-ment of draft.

Shazia Iqbal: Statistical comparison.

Muhammad Irfan Sohail, Fatima Akmal, Ayesha Siddiqui, Ijaz Ahmad and Tayyaba Samreen: Data collection

Muhammad Ashraf: Conclusion summary

Muhammad Naveed and Naveed Iqbal Khan: Methodology preparation.

Rao Masood Akhter: References management.

\section{Conflict of interest}

The authors have declared no conflict of interest.

\section{References}

Agcaoili, M. and M.W. Rosegrant. 2010. Global and regional food supply, demand, and trade prospects to 2010. In: Population and food in the early twenty-first century: Meeting future food demand of an increasing population 1995.

Bahorun, T., O.I. Aruoma, V.S. NeergheenBhujun. 2019. Phytomedicines, nutraceuticals,

June 2021 | Volume 34 | Issue 2 | Page 389 
and functional foods regulatory framework: The African context. In: Nutraceutical and functional food regulations in the United States and around the World. Academic Press. pp. 509-521. https://doi.org/10.1016/B978-0-12816467-9.00032-0

Baral, S.R., Kurmi, P.P., 2006. Compendium of Medicinal plants in Nepal. Rachansharma Publisher, Khatmandu, Neal. Bentley RE. Medicinal Plants. London: Domville-Fife Press; 2010: 23-46.

Bernath, J., 2009. Aromatic plants. In; Fuleky G (ed.) Cultivated Plants, Primarily as Food Sources. EOLSS: Paris, France, pp. 329-352.

Bernholz, C.D., 2004. The united nations commodity trade statistics database (Un Comtrade).

Boesi, A., 2014. Traditional knowledge of wild food plants in a few Tibetan communities. J. Ethnobiol. Ethnomed., 10(1): 75. https://doi. org/10.1186/1746-4269-10-75

Bucher, S.F., A. Ghorbani, G. Langenberger, M. Küppers and J. Sauerborn. 2020. Assessing sustainable use of wild medicinal plants: A case study in the Naban River Watershed National Nature Reserve (NRWNNR), Yunnan/China. Ethnobot. Res. Appl., 9(19): 1-2. https://doi. org/10.32859/era.19.21.1-12

Carrubba, A. and R. Scalenghe. 2012. Scent of mare nostrum Medicinal and Aromatic Plants (MAPs) in Mediterranean soils. J. Sci. Food Agric., 92:1150-1170.https://doi.org/10.1002/ jsfa.5630

Chandresh, G., M.K. Vaidya, R. Sharma and D. Dogra. 2014. Economics of production and marketing of important medicinal and aromatic plants in mid hills of Himachal Pradesh. Econ. Affairs, 55(3): 364-378.

Coghlan, M.L., J. Haile, J. Houston, D.C. Murray, N.E. White, P. Moolhuijzen, M.I. Bellgard and M. Bunce. 2012. Deep sequencing of plant and animal DNA contained within traditional Chinese medicines reveals legality issues and health safety concerns. PLoS Genet., 8: e1002657. https://doi.org/10.1371/journal. pgen. 1002657

Dorni, A.C., A. Amalraj, S. Gopi, K. Varma and S.N. Anjana. 2017. Novel cosmeceuticals from plants. An industry guided review. J. Appl. Res. Med. Aromat. Plants, 7: 1-26. https://doi. org/10.1016/j.jarmap.2017.05.003
Draelos, Z.D., 2019. Cosmeceuticals. In: evidence-based procedural dermatology 2019 Springer, Cham. pp. 479-497. https://doi. org/10.1007/978-3-030-02023-1_30

Field to Market. 2012. Environmental and socioeconomic indicators for measuring outcomes of on-farm agricultural production in the United States: Second Report.

Gunjan, M., T.W.Naing, R.S. Saini, A. Ahmad,J.R. Naidu and I. Kumar. 2015. Marketing trends and future prospects of herbal medicine in the treatment of various disease. World J. Pharm. Res., 4(9): 132-155.

Hamilton, A., 2013. Plant conservation: An ecosystem approach. Routledge. https://doi. org/10.4324/9781849772181

Hamilton, A.C., 2004. Medicinal plants, conservation and livelihoods. Biodivers Conserv., 13(8): 1477-517. https://doi. org/10.1023/B:BIOC.0000021333.23413.42

Joy, P.P., J. Thomas, S. Mathew, G. Jose and J.Joseph. 2001. Aromatic plants. In: Boss TK et al (eds) Tropivcal Horticulture. Odakkali Asamannoor. Kerala, India. pp. 683549.

Karik, U. and M. Tunçtürk. 2019. Production, trade and future perspective of medicinal and aromatic plants in Turkey. Anadolu J. Aari., 29: 154-163. https://doi.org/10.18615/anadolu.660316

Karki, M.B., 2017. Challenges, opportunities and trade-offs in commercialization of medicinal and aromatic plants in South Asia Region. In: Invited paper presented at the workshop on current challenges and recommendations.

Khan, B.A., A. Abdukadir, R. Qureshi and G.H. Mustafa. 2011. Medicinal uses of plants by the inhabitants of Khunjerab National Park, Gilgit, Pakistan. Pak. J. Bot., 43(5): 2301-2310.

Khan, H. and A. Rauf. 2014. Medicinal plants: Economic perspective and recent developments. World Appl. Sci. J., 31(11): 1925-1929.

Kim, S.K., 2016. Marine cosmeceuticals: Trends and prospects. CRC Press; 2016 Apr 19. https:// doi.org/10.1201/b10120

Kuniyal, C.P., P.C. Kuniyal, J.S. Butola, R.C. Sundriyal. 2013. Trends in the marketing of some important medicinal plants in Uttarakhand, India. Int. J. Biodiver. Sci. Ecosyst. Ser. Manage., 9(4): 324-329. https://doi.org/10 $.1080 / 21513732.2013 .819531$

Lange, D. and M. Mladenova. 1997. Bulgarian model for regulating the trade in plant material 
for medicinal and other purposes. Med. Plants For. Conserv. Health Care, 1997: 135-146.

Lange, D., 2006. International trade in medicinal and aromatic plants. In: Bogers, R.J, et al (eds.), Medicinal and Aromatic Plants. Springer, Netherlands, pp. 155-170. https://doi. org/10.1007/1-4020-5449-1_11

Lawson, K., 2013. Botanical and plant-derived drugs: Global markets. BCC Res.,

Mander, M. and G. Le Breton. 2006. Overview of the medicinal plant industry in southern Africa. Commercializing medicinal plants: A southern African guide. pp. 1-9.

Mander M, L. Ntuli, N. Diederichs and K. Mavundla. 2007. Economics of the traditional medicine trade in South Africa: Health care delivery. South African Health Rev., 2007(1): 189-196.

Merry, S.R. and M. Shahjahan. 2013. Country status report on medicinal and aromatic plants in Bangladesh. Expert consultation on promotion of medicinal and aromatic plants in the Asia-Pacific Region: Proceedings. 2013 Dec:75.

Mohapatra, U., S. Rudrapur, D.B. Hiremath and S. Mohapatra. 2018. Medicinal and aromatic plants sector in Karnataka: an economic perspective and SWOT analysis.J.Pharmacogn. Phytochem. SP3. 2018: 232-235.

Montalvo, A.M., E.C. Riordan, and J. Beyers. 2017. Plant profile for Eriodictyon crassifolium. Native Plant Recommendations for Southern California Ecoregions. This article incorporates text from this source, which is in the public domain 2017.

More, B.H., 2019. Natural plant-based ingredient for cosmetic applications: a new era of cosmeceuticals. Int. J. Pharm. Life Sci., 10(6).

National Center for Complementary and Integrative Health, 2011. Archived from the original on 2015-04-05. Retrieved 2011-10-04.

National Center for Complementary and Integrative Health. Retrieved 2011-09-30.

National Institute of Health MedlinePlus. Archived from the original on 2011-10-01. Retrieved 2011-10-01.

National Institute of Health MedlinePlus. Archived from the original on 2011-10-02. Retrieved 2011-09-29.

National Institute of Health MedlinePlus. Archived from the original on 2016-07-05.
Natural medicinal herbs website. Archived from the original on 2017-10-26.

Newmaster, S.G., M. Grguric, D. Shanmughanandhan, S. Ramalingam and S. Ragupathy. 2013. DNA barcoding detects contamination and substitution in North American herbal products. BMC Med., 11: 222. https://doi.org/10.1186/1741-7015-11222

Niyaki, S.A., D.A.Latmahalleh,M.S. Allahyari and P.D. Masooleh. 2011. Socio-economic factors for adoption of medicinal plants cultivation in Eshkevarat region, north of Iran. J. Med. Plants Res., 5(1): 30-38.

Panda, H., 2005. Tagets minuta (wild marigold) an economic crop for hilly reagons. In: Aromatic plants cultivation, processing and uses. Asia Pacific Business Press Inc Dehli, India, pp. 391398.

Paroda, R., S. Dasgupta, Bhag-Mal, S.P. Ghosh and S.K. Pareek. 2013. Expert consultation on promotion of medicinal and aromatic plants in the Asia-Pacific Region: Proceedings. APAARI; Proceedings, Bangkok, Thailand; 2-3 December, 2013.259

Prajapati, B., 2018. Cultivation and bioprospecting of medicinal plants. In: New Age Herbals 2018 Springer, Singapore. pp. 213-245. https://doi. org/10.1007/978-981-10-8291-7_11

Purohit, S.S. and S.P. Vyas. 2004. Marketing of medicinal and aromatic plants in Rajasthan, National consultative workshop on medicinal and artomatic plants, held at GBPUAT, Pantnagar, 2004.

Pyakurel, D., C. Smith-Hall, I. Bhattarai-Sharma and S.K. Ghimire. 2019. Trade and conservation of nepalese medicinal plants, fungi, and lichen. Econ. Bot., 2019: 1-7. https://doi.org/10.1007/ s12231-019-09473-0

Rao, S., S.K. Hegde, M.P. Baliga-Rao, P.L. Palatty, T. George and M.S. Baliga. 2017. An Aloe verabased cosmeceutical cream delays and mitigates ionizing radiation-induced dermatitis in head and neck cancer patients undergoing curative radiotherapy: A clinical study. Medicines. 4(3): 44. https://doi.org/10.3390/medicines4030044

Rasethe, M.T., S.S. Semenya and A. Maroyi. 2019. Medicinal plants traded in informal herbal medicine markets of the Limpopo province, South Africa. Evid. Based Complement. Altern. Med., 2019. https://doi. 
org $/ 10.1155 / 2019 / 2609532$

Roosta, R.A., R. Moghaddasi and S.S. Hosseini. 2017. Export target markets of medicinal and aromatic plants. J. Appl. Res. Med. Aromat. Plants, 7: 84-88. https://doi.org/10.1016/j. jarmap.2017.06.003

Sher, H., A. Aldosari, A. Ali, H.J. de Boer. 2014. Economic benefits of high value medicinal plants to Pakistani communities: an analysis of current practice and potential.J. Ethnobiol. Ethnomed., 10(1): 71. https://doi.org/10.1186/1746-426910-71

Singh, K.M., U. Singh and P. Singh. 2007. A study on role of Atma, Patna in Development of Supply Chain for Medicinal Plants in Patna District, Bihar (India).

The active constituents of herbs, 2013. http://www. health24.com/Natural/Herbs/The-activeconstituents-ofherbs-20120721.

Travis, J., L.G. Lattimore, M. Harvey, T. Frey. 2019. NSF International's role in the dietary supplements and nutraceuticals industries. In: Nutraceutical and functional food regulations in the United States and around the World 2019 Jan 1 Academic Press. pp. 147-158. https://doi. org/10.1016/B978-0-12-816467-9.00011-3

Tripathi, C., A. Girme, S. Champaneri, R.J. Patel and L. Hingorani. 2020. Nutraceutical regulations: An opportunity in ASEAN countries. Nutrition, 74: 110729. https://doi. $\operatorname{org} / 10.1016 /$ j.nut.2020.110729

Van den Bergh, J.C. and F. Grazi. 2014. Ecological footprint policy? Land use as an environmental indicator. J. Ind. Ecol., 18(1): 10-19. https:// doi.org/10.1111/jiec.12045
Vasisht, K., N. Sharma and M. Karan. 2016. Current perspective in the international trade of medicinal plants material: an update. Curr. Pharm. Design., 22(27): 4288-4336. https:// doi.org/10.2174/13816128226661606070707 36

WHO,2003.WHO guidelines on good agricultural and collection practices (GACP) for medicinal plants. World Health Organization.

Williams, V.L., E.T. Witkowski and K. Balkwill. 2007. Volume and financial value of species traded in the medicinal plant markets of Gauteng, South Africa. Int. J. Sustainable Dev. World Ecol., 14(6): 584-603. https://doi. org/10.1080/13504500709469757

Zahra, W., S.N. Rai, H. Birla, S.S. Singh, H. Dilnashin, A.S. Rathore and S.P. Singh. 2020. The global economic impact of neurodegenerative diseases: Opportunities and challenges. In: Bioeconomy for sustainable development 2020 Springer, Singapore. pp. 333-345. https://doi.org/10.1007/978-981-139431-7_17

Zhang, J., B. Wider, H. Shang, X. Li and E. Ernst. 2012. Quality of herbal medicines: Challenges and solutions. Complement. Ther. Med., 20: 100-106. https://doi.org/10.1016/j. ctim.2011.09.004

Zhou, H.Y., E.M. Shin, L.Y. Guo, L.B. Zou, G.H. $\mathrm{Xu}$ and S.H. Lee. 2007. Anti-inflammatory activity of 21 (alpha, beta)-methylmelianodiols, novel compounds from Poncirus trifoliata Rafinesque. Eur. J. Pharmacol., 572(23): 239-248. https://doi.org/10.1016/j. ejphar.2007.07.005 